\title{
デンプンの科学と \\ デンプン䊉の特性
}

\section{1. はじめに}

筆者は阪大教授二国二郎博士と協力して, デンプン研 究留談会 (Starch Round Table) を昭和 35 年化組織 した。こ机はアメリカのコーンスターチ関係の大デンプ ン会社が共同に出資したトウモロコシ工業研究財団 (Corn Industries Research Foundation) で, 各大学 または公立研究所の学者に研究費を提供して,トウモ口 コシ工業の基礎研究を行なっている活動の一つとして, 寸でに 20 年以上前から行なわ机ているデンプン円卓会 議の日本版である。

アメリカの会議に二国教授が出席して，らちとけた討 議と，学者と産業界の技術者が腹蔵のない意見を交換す る協調ぶりに大い洪鳴して帰国後, その日本版をぜひ 組織し, 将来の産学協同の礎石にしたいといらので, 筆 者らが協力して現在まで 5 回を重㸚ている。この会に は, 全国の大学, 国和よび地方の訊験研究機関のデンプ ンの研究者, 諸会社のトップクラスの技術者が集って, 3〜4 日間ホテルで缶詰になって，デンプンの基䃈およ び応用面の諸問題について熱心な討論をたたかわしてい る。

昨年 6 月に行なるれれ第 5 回の席上で, 北大教授中川 鶴太郎博士が叔もしろいことを言われた。自分はデンプ ンのレオロジーの研究を行なっているが，デンプンは高 分子のなかでも特にむずかしいので，レオロジーの研究 者は, 天然ゴムや CMC なたは PVA などのような, 解析のしやすい対象に取組みたがる傾向がある。いい換 えれば，レポートになりやすいテーマにとりつきたがる ようだ。自分などその意味で変り者であろうが, デンプ ンのレオロジーは，むつかしいなかにやればやるほどお もしろ味が出てくるという趣旨であったと思う。われわ れもよく,デンプンの研究はドロ沼のよらなものだと言 い合っている。こ机と思い合わせて実に興味樑く排聞き

* Shigeo SuzUri 農林省食糧研究所園芸食品部長 · 農博

Present Status of the Starch Science Mainly on the Characteristics of Starch Granule
鈴 木 繁 男*

した次第である。しかしドロ沼のようだとはいうもの の，その不思議な趛力には，いったんとら兄られるとな かなか離机がたいものがあって，筆者もデンプンをいじ りはじめてから 20 年を越えてしまった。これはこれま での諸外国の研笁者の業績を見てもその感が強い。たと えばデンプン粒が膨潤してノり化する過程を何年もかか って映画にとったり ${ }^{1), 2)}$, デンプン粒をたんねんに $0.2 〜$ $0.05 \mu$ 程度の薄片にして, 電子顕微 鏡で連続写真をと ってデンプン粒の微細構造晏検討したり ${ }^{3)}$ ，とにかく根 気のいる仕事でよほどデンプンに㴽れこ京水ばできな いことであるす。

本稿では，与兄られた枚数もわずかであり，デンプン

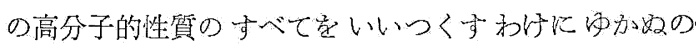
で，編集喤から“単なる教科書的な内容にとどょらず， 夢とか Philosophy がにじみ出た内容にして欲しい”と いらむずかしいご注文もあるので，デンプンの粒子に関 する問題にし淩って，筆者の考え方などおりまぜながら 筆を進めてみたい。

\section{2. デンプンの工業原料としての性格}

箨者は, デンプンまたはブドウ糖のような炭水化物の

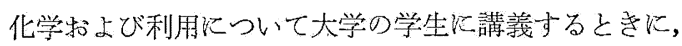
好九で次の言葉を冒頭に述べている。石油化学 (Petrochemical) は世界的に大発展しているが，これはしょせ ん大古から蓄積された資源を，なしくずしに利用しつつ 消粍しているわけである。これに対して木材を総合利用 しようとする，いわば木材化学 (Lignochemical) とも いらべき分野が，アメリカやヨーロッパで注目され，日 本でも企業化の試及がなされたことがある。しかし木材 をこの目的に利用しようとすれば，それに必要な材料を 得るためには，早くても 3〜4 年またはそれ以上の期間 が必要である。しかしデンプンを原料としたブドウ糖か ら出発する総合利用は，ブドゥ糖化学 (Glucochemical) といいらるかもしれないが大きな将来性があうう。その 理由は，デンプン怔当然のとをがら，太陽エネルギー を最も能率良く固定して得られる高分子化合物だからで

「高分子」 
两る。しかも太陽, 地球, 炭酸ガス, 水の共同により栽 培農業が行なわれている限り, 枯渴する心配はない。ま た木材を原料とした木材化学工業では, その主成分であ るへミセルロース，セルロースリグニンを手ぎわ良く 分離せねね゙ならず，このことは化学工学的炕いるいる 困難な点がある。ところがデンプンは他の不純物が少な いので, 容易に, したがって安いコストで,かなり高純 度の状態で分別できる特長がある。価格もキログラムあ たり 40〜60 円程度で, 工業原料としての適格性は十分 化持っている。ところでこれまでのデンプンは，ほとん ぞ大部分が食糧または食品原料として消費されてきた。

すなわち，わが国は諸外国に比校しても有数なデンプ ン生産国である。すなわち年次によりかなりの変動はあ 当がサッマイモデンプン 65〜75 万トン, ジャガイモデ ンプン 16〜20 万トン, 小麦デンプン 5〜8 万トン, ーンスターチ 15 25 万トン, 計 100〜125 万トンであ りかなりの数量である (10 万トンが約丸ビル 1 杯分の 容積に相当する)。今後の方向として, サツマイモデン プンは主としてブドウ糖その他の低分子の糖類生産を目 的とした加水分解面へ利用さ水，ジャガイモデンプンの かなりと，小麦デンプン，コーンスターチの大部分は, 高分子的特性を利用した消費面への用途がをすをす桩大 される傾向である。これら各種のデンプンは，種類によ り艺の高分子的な特性が種々異なって招り, これ案では その独特の物性伈応でた利用面が開発されてきた。今後
はデンプン本来の高分子的性質を化学的改变した，い わゆる化工デンプン，デンプン誘導体が各方面俰用さ れるすう勢で西り，さらにはデンプンの二つの成分す なわらアミロースとアミロペクチンに分別して，それぞ れの化学的特性を利用した各種の用途面が急激炕進展し つつあるのが現状である。

デンプンは植物が次代の幼植物のために用意した貯蔵 物質であるから，七ルロースなどの高分子に比して，非 常に変化を受けやすい性質がある。そこでたと竞ばアミ ラーゼや酸などで容易に加水分解される。これがデンプ ンの利用に際して，都合の良いことも惫いこともある。 前者の例としては，化工デンプンを酸処理法で艒造する 場合や，あるい愔ンプンを紙のノリとして使う際に， デンプンを醰素で処理してかなり自由に性質を変えるこ とができるので，古くから酵素処理デンプンとして，そ れぞれのサイジングに適するように変性して利用されて いることがあげられる。都合の悪い例としては, カルボ キシメチルデンプンいわゆる CMS などがある。これは CMSを原料として，せっかく利用目的に適したノリ液 をつくっても, 自然落下菌のアミラーゼなどで加水分解 されるので, 粘度が急に低下しやすい欠点が指摘されて いる。

次に食品初上び非食品工業原料としてのデンプンの定 義といらと大げさになるが, デンプンの共通の性質をあ げると次のようねならう。

第 1 表 各種デンプンの呿もな特性（鈴木・田村）

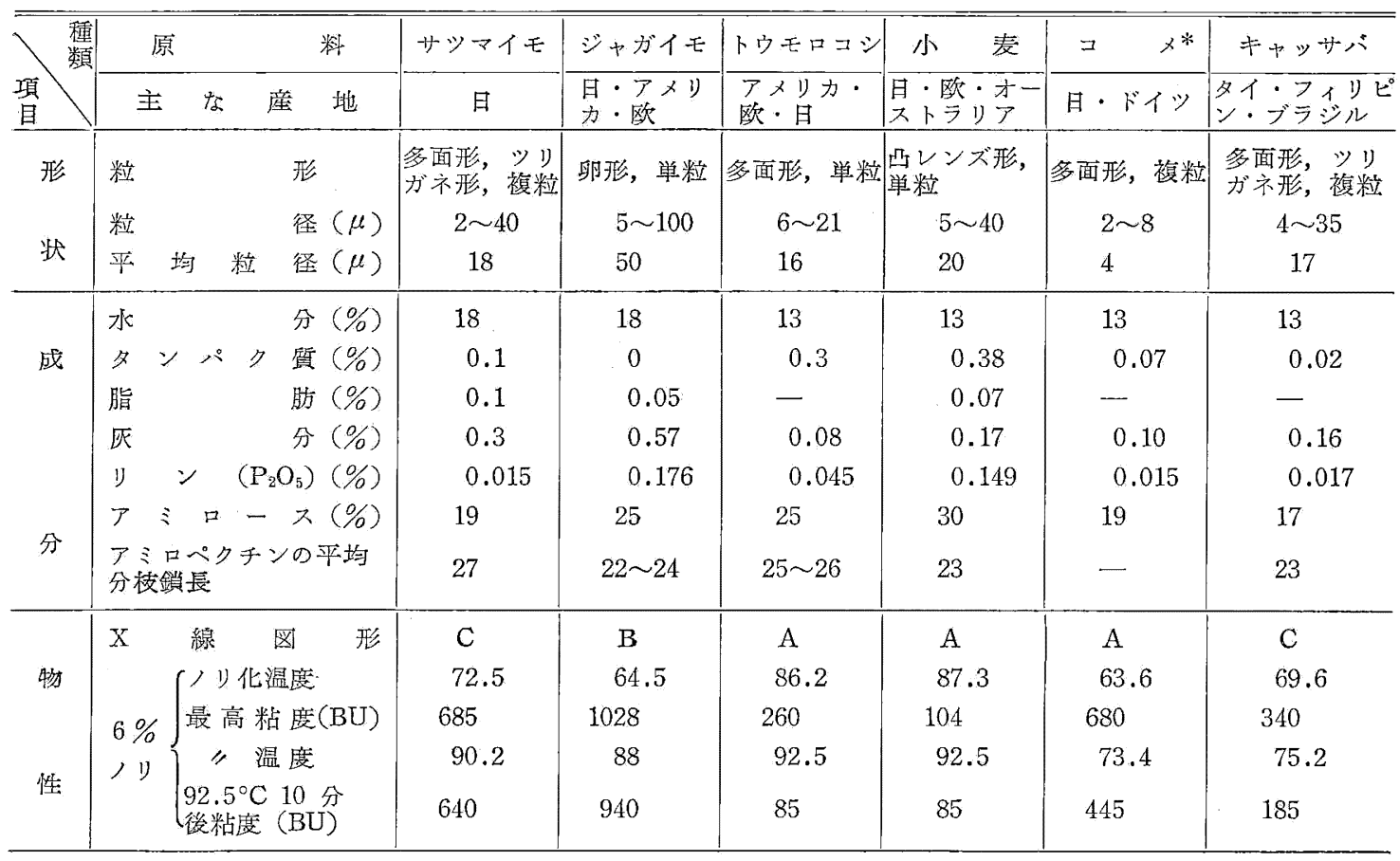

* 表中コメの諸性質は日本コメのものを岕け゚た 
1）ブドウ糖の重合体である。

2）重要な炭水化物で，エネルギー源としての栄養価 がある。

3）各種の微生物や酵素または酸で，かなり容易に分 解される。

4) 冷水に溶けない白色の微粒子 $(1 \sim 150 \mu)$ である。 水に溶忬ず沈殿するからデンプンと言われた歴史が ある。

5）水中で加熱する場合，一定温度（ノリ化温度）を 過ぎると次第に膨潤して，コロイド状のノリ液にな る。このノリの特性は, デンプンの種類により大き く変化する。

6）化学的には直鎖構造のアミロースと分肢構造のア ミロペクチンの高分子同族体の混合物である。普通 その比率は，ほぼアミロース 20２5\%，アミロペ クチン $75 \sim 80 \%$ である。糯(モチ)種の米, トウモ ロコシなどは， $5 \%$ ぐらいアミロースを含むものも あるが，淁とんど全部がアミロペクチンであるとい ってよい。またェンドウの一種である Wrinkled pea や,トウモロコシの中で high amylose corn では 50〜85\%のアミロースを含んでいる。このようなア ミロース含量は, 植物の種類や品種でほぼ一定して いる。

現在工業的に利用されている各種デソプソの主な特性を 第 1 表に示した。

\section{3. デンプンの粒子構造と高分子的特性}

1940 年ごろまでのデンプンに関する諸報告では, デ ンプン粒とデンプン分子, さらにはデンプン分子の化学 構造などの概念が混乱していたが，これを解明したのが K.H. Meyer ${ }^{4}$ のず゙らしい業績である。彼の考党から 今日のデンプン化学が誕生したといってさしつか觉ない であるう。その考光方により，これ亲で不統一で解釈に 苦しんでいたデンプン粒子のいろいろの挙動が理解でき るようになった。Meyer はデンプン分子は, 構造の全く 違う二つの高分子多糖類（同族体といってもよい）アミ ロースとアミロペクチンとの混合物であると考光た。す なわち Meyer は，アミロース抒よびアミロペクチンに 次の明確な定義を与克た。すなわち, “枝分かれしない 分子で $\beta$ アアミラーゼによって完全に梼化される炭水化 物をアミロースといい, 枝分かれ分子で $\beta$-アミラーゼに よって限界デキストリンをでしか分解されない孷水化物 をアミロペクチンと定義する゙。このようにして Meyer が，デンプンは直鎖拉よび分岐状の 2 成分からなる混合 物であることを明らかにしたので，混乱していたデンプ ン化学がようやく整理の緒についたわけである。艺こで デンプンという言葉で諸現象を椧ずる場合は, アミロー ス,アミロペクチンの成分を一緒にして諭ずるか，なた
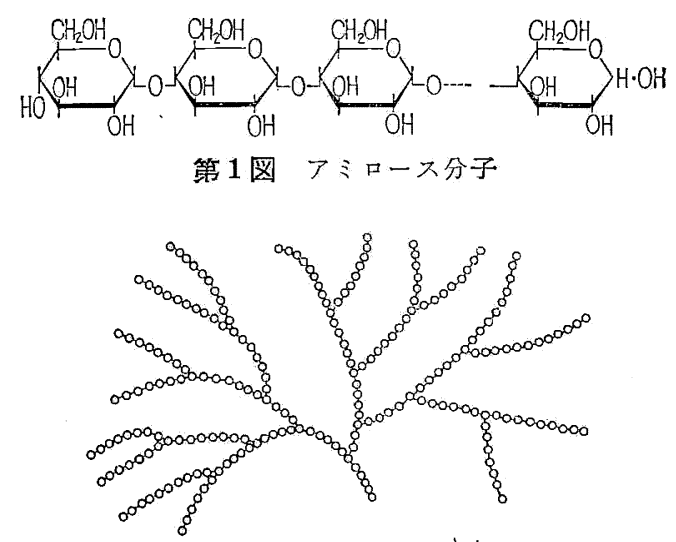

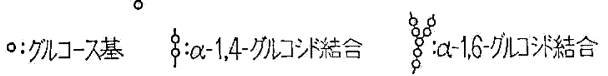
第 2 図 アミロペクチン分子

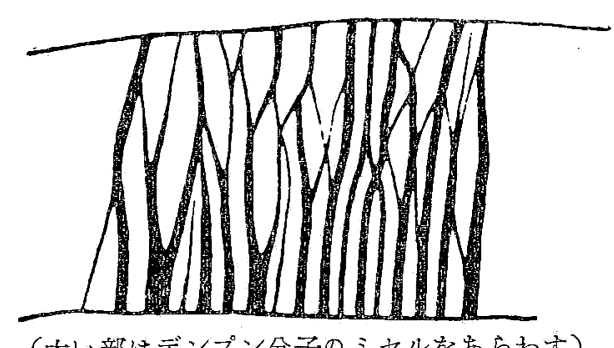

(太い部はデンプン分子のミセルをあらわす）

第 3 図 K. H. Meyer のデンプン粒子内ミセル配列模型

はこの 2 成分の混合物である天然デンプンを指すべき で, 化学構造を諭ずる場合には直鎖成分のアミロースと 分岐成分のアミロペクチンを明確に区別して考学る注意 が必要である。また Meyer の考光たデンプン粒子の模 型は, デンプン粒子の一見無秩序な各種の挙動に, 合理 的な解釉を劣ることに大きな寄与をした。すなわち第 3 図のように, デンプン稙子内にミセルが束のように配 列しているが，それぞれの分子と分子の間には，空陌が かなりあるおけである。この空吵の内部へ，蒸気や液体 や各種の溶質の侵入は十分に可能である。デンプン粒子 の特徵として, 粒子の状態のますで化学反応させても, かなり均等な生成物が得られるが，これは前述の空隙の 部分に蒸気, 液体, 溶質が侵入し, デンプン粒の内部の 弱い部分から反応すると考光れば容易に理解できる。こ のことは各種の化工デンプンの製造の際に有利な性質で ある。たとえばアメりカで紙のサイジング材料として， 化工デンプン中で最も多く利用されている酸化デンプン の製造の場合にも好都合である。これはデンプンの鲧濁 液に, 塭素をたは次亜塩索酸ソーダを加え, $\mathrm{pH} 9$ 程度 のアルカリ性で常温付近で酸化し, 粒子状のまをで洗浄 乙乾燥して製品とする ${ }^{52,6)}$ ものである。この方法は，1) デンプンを粒子状のままで加工処理できること，2）デ ンプンに対する有効塩素の消費量をコントロールする と，酸化の程度を調節できること，3）旮の結果できた 
酸化デンプン製品のノリ液の性状を予測できること, 4) いいかえ机ば，使用目的にかなった酸化デンプンを 製造できることなどの製造上の利点があり,さらに裂品 はノリにした場合に, 粘度が安定で液の透明度が良いな ぞの特長がある。恋た八木けは, 硫酸第一鉄を触媒とし て，デンプンの㲘濁液に過酸化水素とアスコルビン酸の 混合物で酸化して, あらかじめ予測した特定粘度の酸化 デンプンを製造することに成功したが，これも同様に粒 子反応の有利性を活用したものである。

デンプン粒子中のミセルで，分子と分子の近ついたと ころでは, $\mathrm{OH}$ 基の間に水素結合が強く形成されて, 分子 が冷水中へ拡散することが好げられている。そのために デンプン粒子は冷水中で膨潤しないと考えられている。

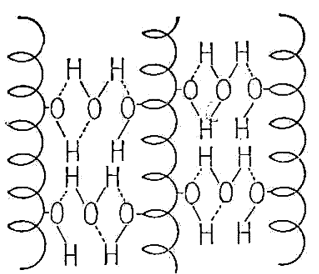

(a)

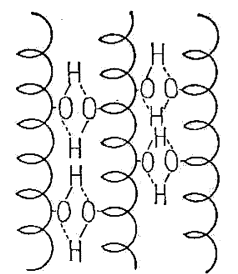

(b)
水分子による間接結合

第 4 図 デンプソミセルの水素結合の模式図

デンプン粒子の平衡水分は穀類デンプンで 10 12\%, イモデンプンで 17〜18\%とかなり異なり，ジャガイモ デンプンを相対湿度 $100 \%$ の湿潤状態で高温処理（100 $\left.\sim 110^{\circ} \mathrm{C}\right)$ すると, 平衡水分や X 線回折図がトゥモロコ シデンプン型沈变る ${ }^{8)}$ こは，デンプンミセル中での水 の, 水素結合への関与の仕方が種類によって異なること を推測させる。

またデンプンのノリ化温度がそれぞれ異なるのも，そ れぞれのデンプンの水素結合の熱エネルギーによる分子 運動に対する抵抗力の差によって起こると考光れば，水 素結合の強弱を示唆するものであるら。いずれにせよ平 衡水分，ノリ化温度，X楾図形などの特性が各種デンプ ンにより相違することは, 第4 図で示したよらな, 水を 介し, 枕はしない水素結合の存在が重要な一つの原 因となるものであるら。

またデンプン粒子は，多孔性微粒子の諸性状を示し， 酸やアルカリを吸着するが，この際 Freundlich の吸着 等温式に彷う。その場合に食塩, 硫酸ソーダ, 硫酸マグ ネシウム（その他硫酸根をるつるの）などの塩類は, 脱水的に作用して水素結合を強めるので，ノり化温度を 高める作用がある。ところがアルカリは，デンプンに吸 着してミセル内の水素結合をといて水和し，ノリ化温度 を低める作用 ${ }^{9}$ がある。また，四 級アミン類は，ア ルカリ攺ど良くデンプンに吸着されないが，デンプンミ セルに契を入れるよらに押し広げるので，やはりノリ化

Vol. 15, No. 168

温度を下げる作用がある10)。屯たデンプン粒子のイオン 交換性も注目すべき性質である。たと充ば，ジャガイモ デンプンは，リン酸残基をかなりもっているので，陽イ オン交換性がある11。ジャガイモ細胞内にある時は，カ リウム塩型のジャガイモデンプンが，デンプン製造の際 に使用水中のカルシウムイオンやマグネシウムイオンを 交換して，その条件汅よりジャガイモデンプンのノリ液 の粘度が变化することも知られている ${ }^{12)} 。$

\section{4. デンプン粒の結晶性}

デンプン粒の中のアミロースとアミロペクチンは 3 . でもられたよらに，無秩序に集っているものでなく，一 種の球晶と考えられている。偏光顕徽鏡で性黒十字の複 屈折が見られ，X線粉末法では結晶様の回折図形が得ら れることはよく知られている。デンプンのX線回折像に

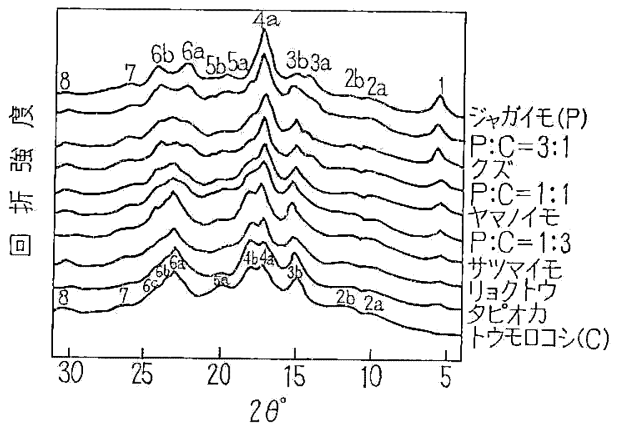

$20=4^{\circ}$ K和ける回折強度を一定にしてトウ モロコシ ( $\mathrm{A}$ 形) からジャガイモ (B形) まで重ねたもの，中間のものはすべてC形

第 5 図 天然デンプンのX線回折図形

は，トウモロコシデンプンで見られるA図形と，ジャガ イモデンプンのB図形とがある。その他の各種のデンプ ンのX線回折像は，AとBの漂か両者の中間に相当する ものがあり，C図形と四ばれていた。ところがこれらを ならベて見ると第 5 図のよらに一種のスペクトル模様が 得られ，C図形を示すデンプンは，現在ではAとBの種 種の彗合の混合物であると考えられるよらになった。

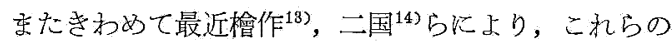
結晶形は植物の生育する環境条件（主として温度）に より変化し，これ变で考学られていたように植物の種 (Species) で固定したものでないことが明らかにされ た。デンプン粒はこのように結晶質であるが，全部が結 晶状になっているものでなく，いわゆるミセル構造（第 3 図) であって，結晶の部分もあ机ば非晶質の部分もあ る。々の結晶化度はX 線法で測定できるので(5),16)，ジ ヤガイモは $25 \%$ 程度, トウモロコシ,コメ, サッマイ モなどは $40 \%$ 程度であることが知られている。ここで デンプンの結晶性に関してはアミロペクチンの影響が大 きいことが考党られる ${ }^{17}$ すなおらデンプンから分離し たアミロースは，きわめて結晶しやすいが，デンプン粒 
子のアミロース含量が多いものほど結晶化度が少ないの で現在のところアミロペクチンのミセル部分が結晶化 し，アミロースはその間に不定形にうずまっているもの と考えられている。これはデンプソ学温水で浸出すると， アミロースが容易に溶出することからもらかがわれる。

\section{5. デンプン粒の反応の特異性}

デンプン粒の形態については，19世紀ごろ多数の植物 学者の研究があり, その化学構造は 1940 年ごろに多数 の高分子学者によって研究されたが，3.で述べたよう に K.H. Meyer により新しい見解に統一された。また デンプンの合成酵素については，これまでホスホリラー ゼが主体と考光られていたが，きわめて最近 Leloir ${ }^{18) や ~}$ 赤沢ら ${ }^{19}$ にょって, アデノシン二リン酸グルコースのグ ルコース（第 6 図）をデンプン分子に転位して， $\alpha-1,4$ 結合をつくる酵素があること，またこの際にデンプン粒 子自体が一つの複合酵素系のように作用することを明ら かにし，画期的な進展を遂げた。

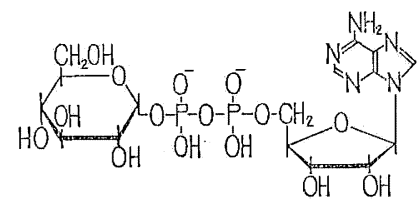

第 6 図 アデノシソ二リソ酸グルコース

天然のデンプンを顕微鏡で見ると, 大きさと形態が違 ら微小な粒子の混合物である。この粒子の大小により， デンプンの性状は大きく変化する。たと竞ばノリ化に対 する抵抗性が異なり，一般に同一のデンプンでは，大粒 子の方が小粒子よりはるかにノり化しやすい。またアミ ラーゼなどの醳意作用や，いろいろの反応試楽に対する 抵抗性も小粒子の方が大きい。さらになた，一粒のデン プン粒に限っても, 外部から熱その他の物理的をたは薬 品による化学的の作用を与交た場合には, それにより与 える变化は，決して全面的燋行するのでなく，デンプ ン粒子の部位によりその速度が非常に異なることがわか った。たと充ば酵素による消化に対しては，デンプン粒 の内部の方が外部より抵抗性が弱いことが, 超薄マイク ロトーム切片の電子顕微鏡観察によって知られてい

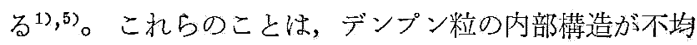
一であること走するので，デンプン分子の構造的配位 の粗密, または結晶構造の強弱が，外部から与えられた 酵素的, 化学的, 物理的作用に対して, 部分的に反応す るためと解䐆してよい。このようにデンプンの性質，特 にデンプンの内部構造に基く物理的諸性質を諭ずる場合 に，デンプンが均質な一定した物質でなく，アミロー ス，アミロペクチンといら高分子多糖類の複雑な混合物 であり，しかもその配列により結晶的性格が異なること に注目する必要がある。そこで天然デンプンのいろいる
の性質一一たとえば粒子のまま加熱するとか，酸を作用 させる場合に見ら机る反応など——は，艺机ぞれのデン プン粒の個々の性質の総和として現われてくることにな る。デンプンを塩化ビニルなど単なる高分子化合物の粉 末の混合物のように考えてその挙動を解析するわけにゆ かない理由がこれである。

\section{6. む す び}

以上デンプン粒の高分子的特性について概説してきた が，デンプン粒の性状，特にデンプン粒に水を加えて加 熱する際にノリ化する特性，そのノリ液の性状，デンプ ンに少量の水を加え加熱ノリ化させて，デンブン粒のあ る位置での接着力を段ボールその他に利用する gelati nization in situ，アミロースによる皮膜その他與味ある 問題が多い。本稿がこれらの諸問題への興味を㖟起し， デンプンの研究に近づく何らかのきっかけになれば管者 の望外の幸である。日本でのデンプン粒についての研究

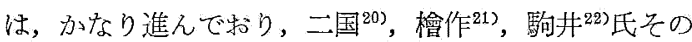

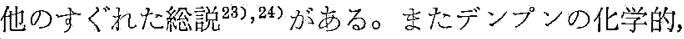
物理的性質の詳細については，それぞれの面で特徽のあ

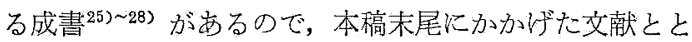
もに参照していただきたい。

\section{交献}

1) Z. Nikuni, R. L. Whistler: J. Biochem. (Japan), 44., 227 (1957)

2）二国二郎：電子顕微鏡によるデンプン粒の研究，4, 12 (1959) · 蛋白質核酸酵素

3) R. M. Sandstedt: Cereal Chem. Supplement, 32, No. 3, 17 47 (1955); Gelatinization of Potato Starch 16 ミリ映画 (1957)

4) K. H, Meyer, P. Bernfeld: Helv. Chim. acta, 23, 890 (1940)

5) R. L. Mellies, C. L. Mehltretter, I. A. Wolf: Ind. Eng. Chem., 50, No.9, 1311 (1958)

6) R. L. Whistler, R. Schweiger: J. Am. Chem. Soc., 79, No. 20, 6460 (Dec 1957)

7）八木一交，鈴木博久：昭和 39 年度日本農芸化学会大 会講演要旨集, 252 (1964)

8) L. SAIR, W.R. Fetzer: Ind. Eng. Chem., 36, No. 3, 205 208 (1944)

9) H.W. Leach, T.J. Schoch, E. F. Chessmann: Die Stärke, 13, No. 6, 200 (1961)

10) J. Muetgeert, P. Hiemstra, W.C. Bus: Die Stärke, 10, No. 12, 303 (1958)

11) H. Wegner: Die Stärke, 19, No. 10, 196 (1957)

12) G. Tegge., W. Kempf: Die Stärke, 13, No. 8, 292 (1961)

13) S. Hizukuri, M. Fujii, Z. Nikuni: Natare, 192 , 239 (1961)

14）二国二郎, 檜作 進, 藤井ミ子子, 土并健二, 長谷 川浩, 森脇 勉, 奈良省三, 前田 厳：日農化, 37,673 (1963) 
15) H. F. Zobel, F. R. Senti: Program of 45 th Annual Meeting of American Association of Cereal Chemist, 40 (1960)

16) C. Sterling: Die Stärke, 12, 182 (1960)

17）懀作 進, 藤井ミ子子，二国二郎：日本農芸化学会 大会講演要旨集，4:(1960)

18) L.F. Leloir: Biochem. J., 94, 1 (1964)

19）赤沢 圭：化学々生物，3，No. 6, 282 (1965)

20）二国二郎：農化，30，A 131 (1956)

21）檜作 進：化学々生物，2，No. 6, 282 (1964)

22) 駒井嘉彰: 化学々工業, 16, No. 5, 563 (1963)

23) 福井俊郎: 化学, 19, No. 1, 44 (1964)
24）鈴木繁男：魚肉ソーセージ研究の進歩第 1 集（昭和 34年10月10日）全国魚肉ソーセージ協会（澱粉の性

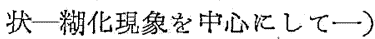

25) R. W. Kerr: "Chemistry and Industry of Starh" 2nd Ed. Academic Press Inc. Pub. (1950)

26) J. A. Radlay: "Starch and its Derivatives 3 rd. Ed. Chapman \& Hall Ltd. London, I, II, (1953)

27) 二国二郎：デンプンハンドブック，(1960) 朝倉書店

28）二国二郎：デンプン; 大有機化学，20，天然高分子 化合物 II, 81 172（1959）朝倉畫店

\section{海外文献紹介誌「海外高分子研究」内容紹介 Vol. 12，No. 3 (通巻 100 号)}

1965年 3 月号雑誌掲載論文題目 $65-\mathrm{L}-19$

（42），二官能性有機ヶイ素化合物特よびそのポリマーの合成と性質

（43）アソチモン化合物によるテトラヒドロフランの重合

（44）カラム法で分別したポリスチレンの粘度数と分子量

(45) ポリビニルアルコールの溶液中に打りる棈造形式

（46）濁度滴定法による高分子の溶解度曲線の測定

(47) ホルムアルデヒドの新しい熱安定性共重合体

(48)リビング重合に和けるモノマー移動

（49）メタクリル酸メチルの酸化禁止とその重合 II 芳香族アミンの効果

（50）環状シロキサンの酸触媒重合 第 1 報 無水塩化第 2 鉄一塩化水素によるオクタメチルシクロテ トラシロキサンの重合の動力学

(51) スチレンーブタジェンラテックスヘのキレートモノマーのグラフト重合

(52) ポリベンジルの酸化分解

(53） sec-フマレートとスチレンとの共重合

(54) オレフィンのチーグラー重合 第 5 報 電子供与体による Site Removal と Site Activation

(55) テトラヒドロフラン中でのナトリウムーポリスチレンのアニオン重合と電解解離

(56) アニオン重合による単分散立体規則性ポリメタクリル酸メチル

(57) ポリー $\alpha$-シアノスチレン

（58） ポリー1,3-シクロヘキサジェンの合成と芳香族化特よび架橋 II

（59）環化重合機構による 4-ビニルシクロヘキセンの重合

（60）ミネラルを触媒とする反応Ｉスチレンの重合

\section{Vol. 12 No. 4 (通巻 101 号)}

1965年 4 月号雑誌掲載諭文題目 $65-\mathrm{L}-27$

（61）水の存在下に叔けるトリオキサンの重合の動力学

(62) 微量の水の存在下に叔々゙リオキサンのカチオン重合について

(63) ポリアクリレート拈よびョポリアクリレートと有機アンモニウムカチオンとの相互作用

(64）電子供与体を添加した $\mathrm{TiCl}_{3}+\mathrm{Al}\left(\mathrm{C}_{2} \mathrm{H}_{5}\right)_{3}$ 触媒系によるプロピレンの重合

(65) 高分子結晶化の動力学—アーアソタクチックポリスチレンー

（66）架橋反応によるゾル生成分率からポリイソプレンの分子量分布の決定

(67) ラジカル重合に特ける拡散律速停止

(68) ポリ（クロルアルデヒド）、ポリクロラールの安定化 II. クロラールの重合

(69) メタクリル酸メチルのアニオン重合機構 IV 二分子的交撸反応による可逆停止反応からの分子量分布の計算

（70）ブタジェンの触媒によるオリゴメリゼーション拉よび共オリゴメりゼーション

（71）トリオキサンのカチオン重合の移動反応による熱安定性末端基を有するポリオキシメチレンの生 成について

（72）トリオキサンのブロック共重合物とグラフト共重合物

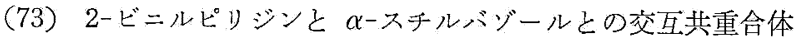

(74）トリエチルアルミニウムージシクロヘキシルパーオキシジカーボネート系による極性モノマーの ラジカル重合

(75) ポリオキシェテレンの Configuration

（76）相容性ポリマー混合物のガラス転移温度 